\title{
Secular evolution of continental crust: recorded from massif-type charnockites of Eastern Ghats belt, India
}

\author{
Samarendra Bhattacharya ${ }^{1}$, Ashwini Kumar Chaudhary ${ }^{2 *}$ \\ ${ }^{1}$ Indian Statistical Institute, Kolkata, India; \\ ${ }^{2}$ Indian Institute of Technology, Roorkee, India; *Corresponding Author: samar.bhattacharya@gmail.com.
}

Received 15 July 2010; revised 18 August 2010; accepted 23 August 2010.

\begin{abstract}
It is reasonably well established that the Earth has substantially cooled from the Archean to the present and hence the sites, rates and processes of crust formation must have changed through geologic time. Archean and Proterozoic granitic rocks are the principal record of such changes. Massif-type charnockites in the Eastern Ghats granulite belt, India, of Archean and Proterozoic ages mirror the changing conditions and/or processes of continental crust formation. Though both can be explained by dehydration melting of mafic rocks, the conditions differ. Potasium and rubidium rich Proterozoic charnockites have significant negative Eu anomaly indicating melting at shallow depths in the stability field of plagioclase. In contrast, sodium and strontium rich Archean charnockites with less LREE enrichment and less depletion in Eu indicate melting at greater depths in the stability field of garnet or amphibole.
\end{abstract}

Keywords: Secular changes; Continental crust; Massif-charnockites; Eastern Ghats

\section{INTRODUCTION}

The continental crust comprising byouant quartzofeldspathic materials are difficult to destroy by subduction and hence can be considered as the principal record of crustal evolution through geologic time. New continental crust may form magmatically from underlying mantle. However, mantle melting products are predominantly basaltic, whereas continental crust is andesitic which can not be extracted directly from melting of mantle-peridotite. Continental crust formation therefore requires a second stage/or event of fractional crystallization [1] or remelting of basaltic magma [2]. Although there remains considerable debate on the processes of crust formation in the Archean compared to those operating in the later period (post-Archean), significant differences in key geochemical features have been documented between Archean and later granitic rocks [3-5]. Moreover, tectonic setting for Archean magmatism as exemplified by TTG remains unresolved. Partial melting may have taken place in subducted slabs $[6,7]$ or in underplated basalt beneath thickened crust or oceanic plateau [8]. TTG suites of Archean greenstone belts are taken as the Archean continental crust, while large varieties of Proterozoic granitic plutons represent the Proterozoic continental crust (cf. Table 3 in [2]). These authors have presented extensive discussion on these differences from a Granitic perspective and their possible implications on the changing processes and or conditions of crust formation from Archean to Proterozoic times.

Eastern Ghats granulite belt, India, comprises massiftype charnockite as a major component in the regional granulite terrane, and there is unambiguous evidence of different generation of such charnockites. Archaean charnockites have been described from northern margin against Singhbhum craton and western margin against Bastar craton [9-11]. Some of the massif-type charnockite suites in the central part of the granulite belt record only Proterozoic ages $[12,13]$. Although, some workers have described magmatic charnockites from the Eastern Ghats, presumably as mantle-derived melt [14], it is difficult to postulate silicic melts directly from mantle-melting. On the other hand, some workers consider enderbitic charnockites of the Eastern Ghats belt as metamorphosed igneous precursors and commonly describe them as "now enderbite" [15]. Here again, the question of felsic igneous rocks directly derived from mantle remains unresolved. Dehydration melting experiments have demonstrated that silicic melts of tonalitic, granodioritic and granitic compositions are produced at 8-10 Kbar, and $\geq$ $850^{\circ} \mathrm{C}$ from mafic rocks [16-18]. The massif-type charnockites in the Eastern Ghats belt are of variable composition and P-T conditions of granulite facies metamorphism are comparable to the experimental constraints as mentioned above $[19,20]$. Thus a remelting of mantle- 
derived melt or hydrated amphibolite under granulite facies conditions could be the favored model for the massif-type charnockites of the Eastern Ghats belt [2022].

Considering charnockite-massifs as products of partial melting in the deep crust under granulite facies conditions, U-Pb ages of zircons in them can be taken as representing this deep crustal anatexis, while the $\mathrm{Nd}$-model ages could provide the mantle-derivation ages of their protoliths.

In this communiqué, we present selected geochemical and isotopic data for two sets of massif-type charnockites of the Eastern Ghats belt, of Archean and Proterozoic ages respectively. These data could mirror the differences in some key geochemical features of the continental crust. These distinctive features may also provide some useful constraints on changing processes of crust formation from Archean to Proterozoic.

\section{GEOLOGICAL SETTING}

The Eastern Ghats granulite belt skirting the eastern coast of India is bounded by granite-greenstone belts of Singhbhum and Bastar cratons to the north and west respectively (Figure 1). The granulite lithologies record polyphase deformation and possible multiple granulite facies imprints [23-26]. Massif-type charnockite is a

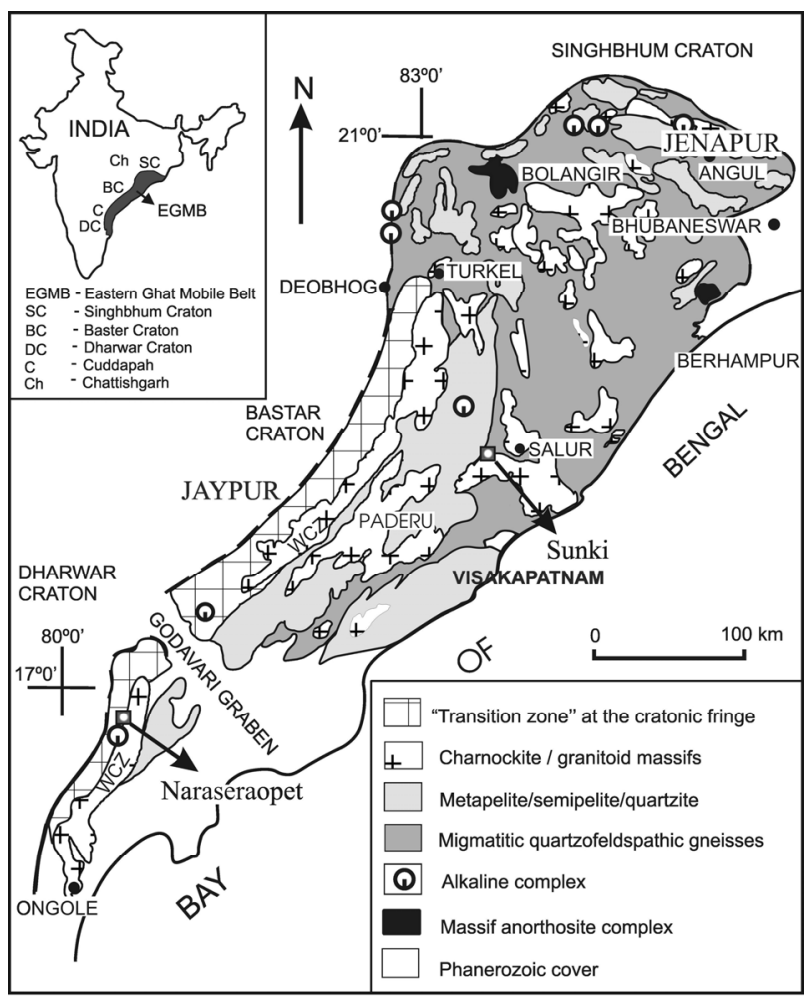

Figure 1. Generalized geological map of the Eastern Ghats Granulite belt, India. major component in this regional granulite terrane and occurs in different crustal domains [10]. The charnockite-massifs considered here occur in the Archean domains around Jenapore \& Jaypur and Proterozoic domains around Sunki, Paderu and Naraseraopet (see locations in Figure 1).

\section{GEOCHEMICAL SIGNATURES}

Bulk composition was determined by XRF spectrometry at National Geophysical Research Institute, Hyderabad and Operating condition for XRF machine was 20/ $40 \mathrm{KV}$ for Major oxides, nominal analysis time was 300 seconds for all major oxides. For the XRF analysis the overall accuracy ( $\%$ relative standard deviation) for major and minor oxides are given as less than 5\%. The average precision is reported as better than $1.5 \%$. For ICPMS analysis at Institute Instrumentation Centre, Indian Institute of Technology, Roorkee, the average precision were $4.1 \%$ RSD.

The analytical data are given in Table 1. Compared to the Archean charnockites the Proterozoic charnockites are potash-rich, with high $\mathrm{K}_{2} \mathrm{O} / \mathrm{Na}_{2} \mathrm{O}$ ratios (Figure 2) and this is consistent with the compositions of granitic rocks of the two periods, as described in Kemp and Hawkesworth, 2004 [2]. Compared with the Archean charnockites the Proterozoic charnockites are rubidium-rich with high $\mathrm{Rb} / \mathrm{Sr}$ ratios (average 1.01, $\mathrm{n}=11$ : Proterozoic and average $0.18, \mathrm{n}=7$ : Archean). The lower $\mathrm{Rb} /$ $\mathrm{Sr}$ ratios in the Archean charnockites reflect elevated $\mathrm{Sr}$ in the Archean than in the Proterozoic charnockites (Figure 3). However, $\mathrm{Sr} / \mathrm{Nd}$ and $\mathrm{Nb} / \mathrm{La}$ ratios are variable in both sets (Figure 4); though lower $\mathrm{Nb} / \mathrm{La}$ ratios in many samples from Archean could reflect different processes in the Archean [2]. Greater fractionation of HREE, extending to higher $(\mathrm{Gd} / \mathrm{Yb})_{\mathrm{N}}$ ratios in the Archean charnockites is consistent with those in Archean greenstone belts (Figure 5). REE patterns are distinctive, primarily in the significant Eu depletion in the Proterozoic charnockites and much less Eu depletion in the Archean charnockites. Significant Eu-depletion coupled with Srdepletion is characteristic of the Proterozoic charnockites compared with those of the Archean charnockites (Figure 6). Archean charnockites show relatively less enrichment in LREE, much less Eu-depletion and greater fractionation of HREE, compared to those in the Proterozoic charnockites.

\section{ISOTOPIC SIGNATURES}

Mantle-derivation ages for the charnockite suites were determined by $\mathrm{Sm}-\mathrm{Nd}$ isotopic analysis of whole rocks by Thermal Ionisation Mass Spectrometry at Indian Institute of Technology, Roorkee. Detail analytical proce- 


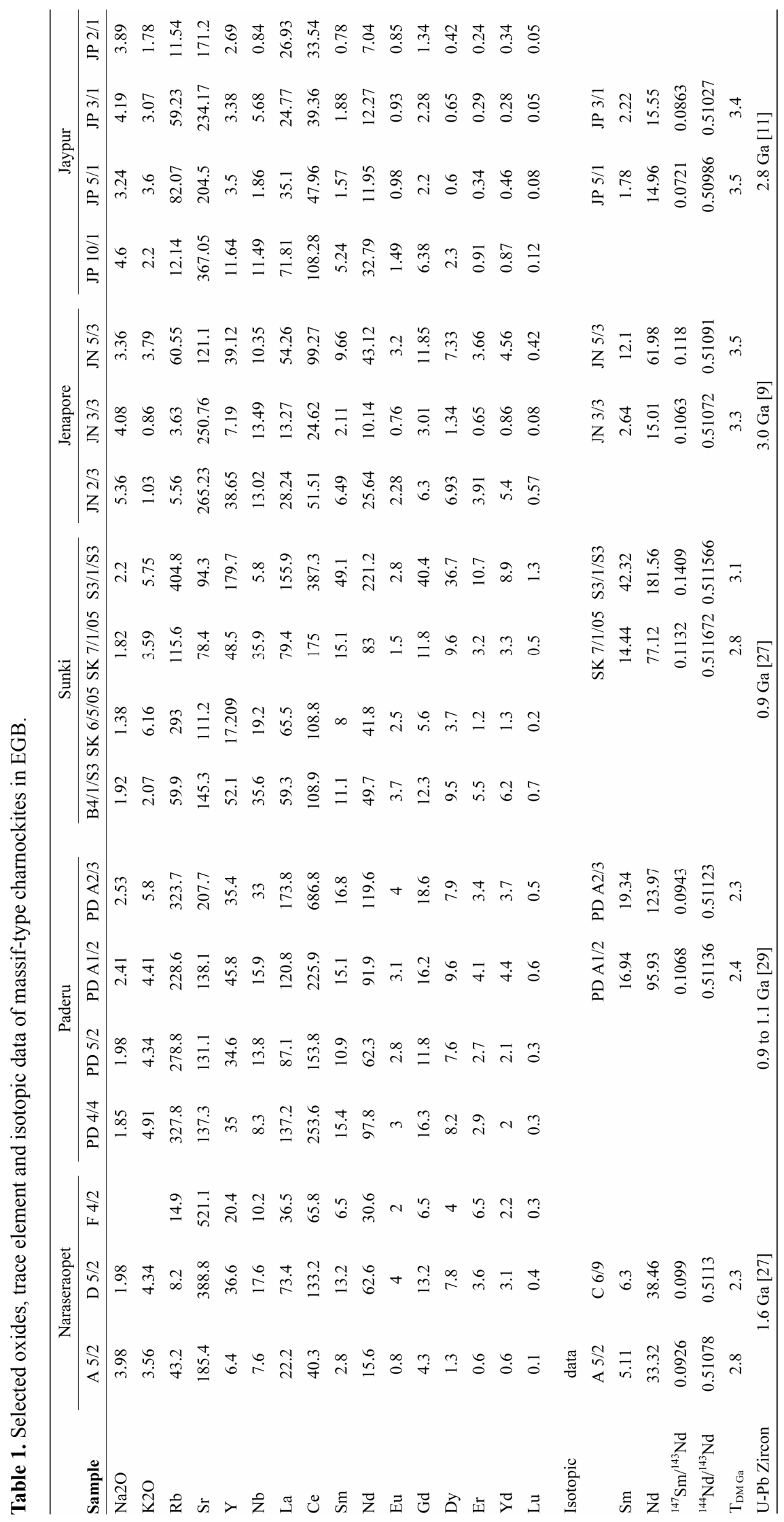




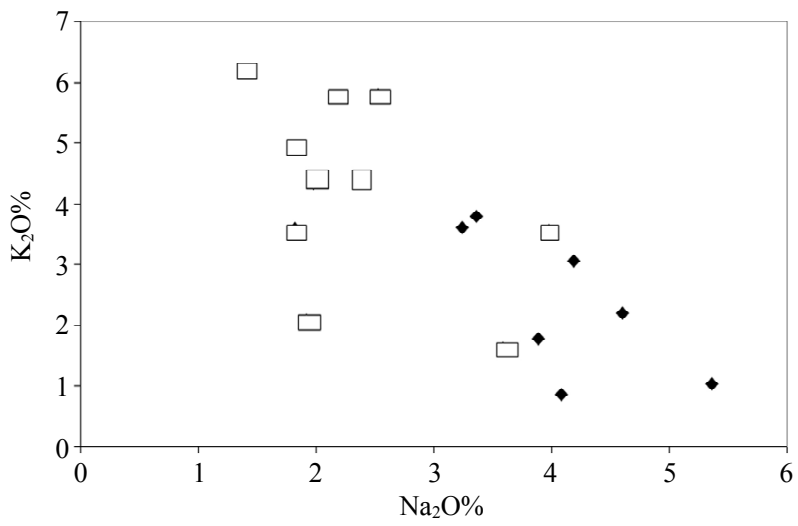

Figure 2. $\mathrm{K}_{2} \mathrm{O}$ versus $\mathrm{Na}_{2} \mathrm{O}$ plot of the charnockites in the Eastern Ghats Granulite belt. Archean charnockites: solid symbols; Proterozoic charnockites: open symbols.

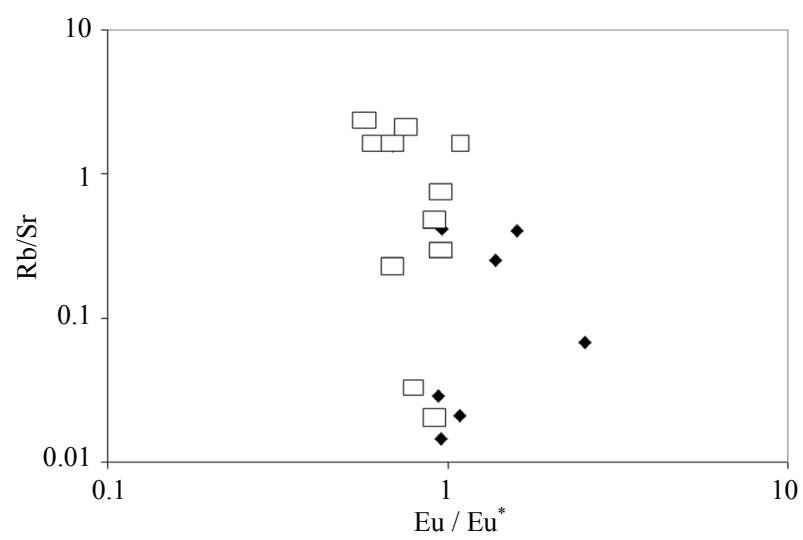

Figure 3. $\mathrm{Rb} / \mathrm{Sr}$ versus $\mathrm{Eu} / \mathrm{Eu}^{*}$ plot of the charnockites in the Eastern Ghats Granulite belt. Symbols as in Figure 2.

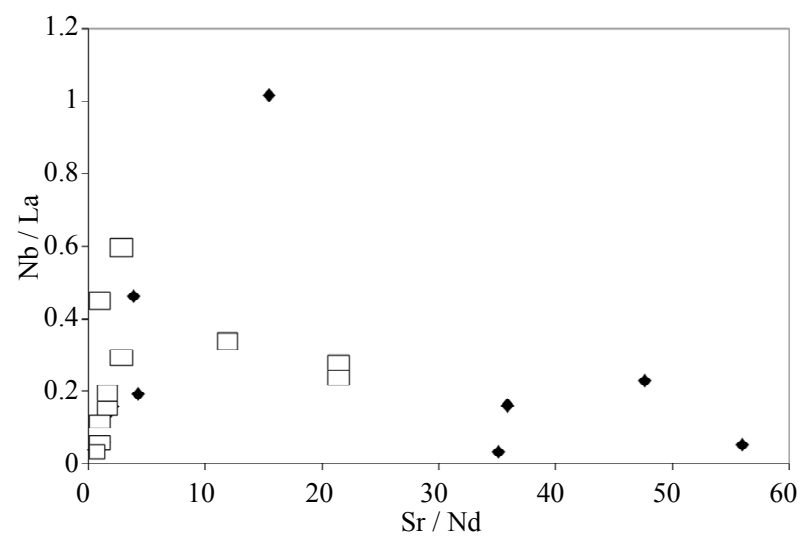

Figure 4. $\mathrm{Nb} / \mathrm{La}$ versus $\mathrm{Sr} / \mathrm{Nd}$ plot of the charnockites in the Eastern Ghats Granulite belt. Symbols as in Figure 2.

dure is given in Bhattacharya et al., 2010 [27]. Measured ratios for isotopic composition are normalized to ${ }^{146} \mathrm{Nd} /$ ${ }^{144} \mathrm{Nd}=0.7219$ for $\mathrm{Nd}$. The measured ratio of ${ }^{143} \mathrm{Nd} /$ ${ }^{144} \mathrm{Nd}$ for Ames Nd Standard was $0.512138 \pm 4$ (quoted

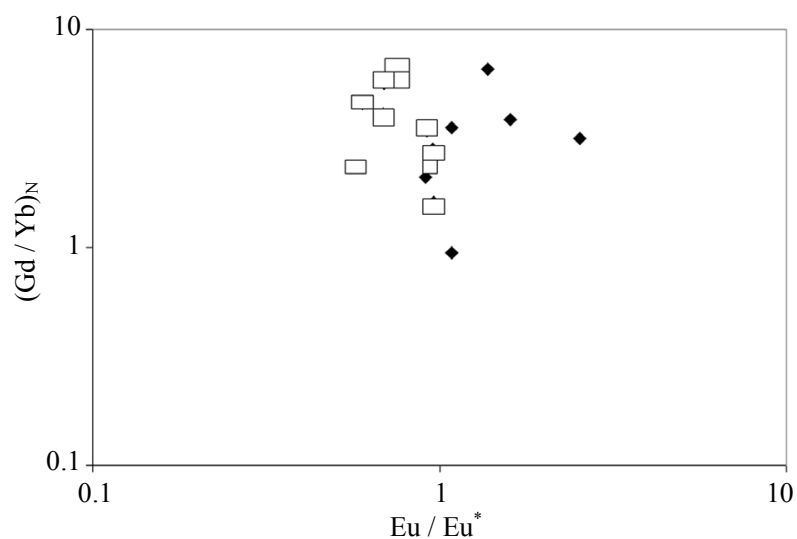

Figure 5. $(\mathrm{Gd} / \mathrm{Yb})_{\mathrm{N}}$ versus $\mathrm{Eu} / \mathrm{Eu}^{*}$ plot of the charnockites in the Eastern Ghats Granulite belt. Symbols as in Figure 2.

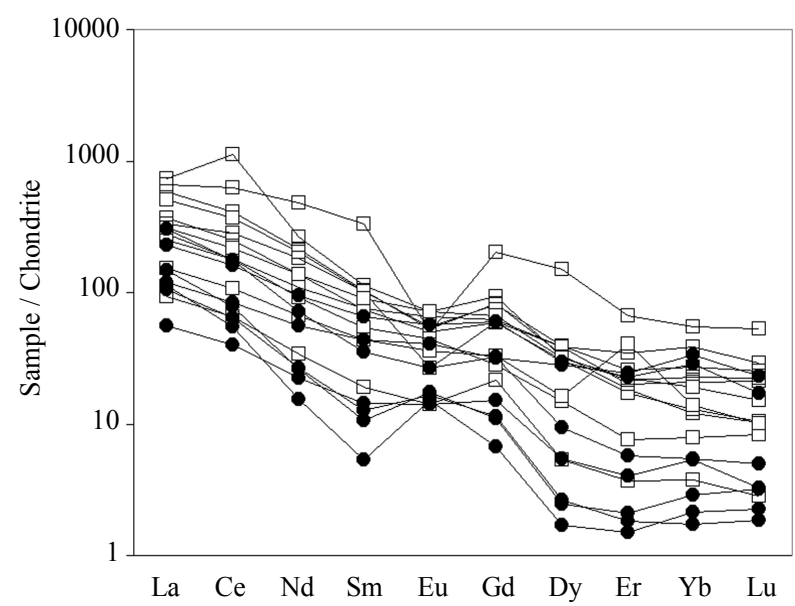

Figure 6. Chondrite normalized REE plot of the charnockites in the Eastern Ghats Granulite belt.

value 0.512138 ).

Mantle-derivation ages $\left(\mathrm{T}_{\mathrm{DM}}\right)$ for the Proterozoic charnockites vary between 2.3 and $2.8 \mathrm{Ga}$ (Naraseraopet), between 2.3 and $2.4 \mathrm{Ga}$ (Paderu) and between 2.8 and 3.1 Ga (Sunki) and those for the Archean charnockites vary between 3.3 and $3.5 \mathrm{Ga}$ (Jenapore) and between 3.4 and 3.5 Ga (Jaypur) respectively (Table 1).

\section{DISCUSSIONS}

High $\mathrm{Rb} / \mathrm{Sr}$ ratios and significant negative Eu-anomalies in the Proterozoic charnockites indicate residual plagioclase. The implication is that intracrustal melting occurred at shallow depths, in the stability field of plagioclase. In contrast, low $\mathrm{Rb} / \mathrm{Sr}$ ratios, indicating elevated $\mathrm{Sr}$, and lack of significant negative Eu-anomalies in the Archean charnockites are indicative of intracrustal melting at greater depths in the stability field of garnet or amphibole [2]. 
Large discrepancies between crystallization ages (of anatectic charnockitic melt), given by $\mathrm{U}-\mathrm{Pb}$ zircon ages reported in the literature (Table 1) and mantle derivation ages given by $\mathrm{T}_{\mathrm{DM}}$ for the Proterozoic charnockites confirm that older crustal material was present within the source regions of the charnockitic magma [28]. This is in contrast to the relatively little time gap between crystallization ages and Nd-model ages for the Archean charnockites, similar to those observed in Archean TTGs.

\section{CONCLUSIONS}

These differences in the geochemical and isotopic signatures between Archean and Proterozoic charnockites reflect different conditions of crust formation rather than different processes: both can be explained by dehydration melting of hydrated basalt or amphibolite under granulite facies conditions; but Proterozoic charnockites at shallower depths (in plagioclase-stability field) than Archean charnockites (in garnet or amphibole-stability field).

\section{ACKNOWLEDGEMENTS}

Indian Statistical Institute, Kolkata provided the infrastructural facilities. Financial support was provided by the Department of Science and Technology, Government of India, in the form of a research project.

\section{REFERENCES}

[1] Soesoo, A. (2000) Fractional crystallization of mantlederived melts as a mechanism for some I-type granite petrogenesis: An example from the Lachlan Fold Belt, Australia. Journal of Geological Society, 157, 135-149.

[2] Kemp, A.I.S. and Hawkesworth, C.J. (2004) Granitic perspectives on the Generation and secular evolution of the continental crust. Treatise on Geochemistry, 3, 349411.

[3] Taylor, S.R. and McLennan, S.M. (1985) The continental crust: Its composition and evolution. Blackwell Publishing, Oxford.

[4] Taylor, S.R. and McLennan, S.M. (1995) The geochemical evolution of the continental crust. Reviews of Geophysics, 33, 241-265.

[5] Rudnick, R.L. and Gao, S. (2004) Composition of the continental crust. Treatise on Geochemistry, 3, 1-65.

[6] Condie, K.C. (1998) Episodic continental growth and supercontinents: A mantle avalanche connection? Earth and Planetary Science Letters, 163, 97-108.

[7] Martin, H. (1995) Archean grey gneisses and genesis of continental crust. In: Condie, K.C. Ed., Archean Crustal Evolution, Elsevier, Netherlands, 205-260.

[8] Whalen, J.B., Percival, J.A., McNiccol, V.J. and Longstaffe, F.J. (2002) A mainly crustal origin for tonalitic granitoid rocks, superior province, Canada: Implications for late archean tectonomagmatic processes. Journal of
Petrology, 43, 1551-1570

[9] Bhattacharya, S., Kar, R., Misra, S. and Teixeira, W. (2001) Early Archaean continental crust in the Eastern Ghats granulite belt, India: Isotopic evidence from a charnockite suite. Geological Magazine, 138, 609-618.

[10] Rickers, K., Mezger, K. and Raith, M. (2001) Evolution of the continental crust in the Proterozoic Eastern Ghats belt, India and new constraints for Rodinia reconstruction: Implications from $\mathrm{Sm}-\mathrm{Nd}, \mathrm{Rb}-\mathrm{Sr}$ and $\mathrm{Pb}-\mathrm{Pb}$ isotopes. Precambrian Research, 112, 183-210.

[11] Kovach, V.P., Simmat, R., Rickers, K., Berezhnaya, N.G., Salnikova, E.B., Dobmeier, C., Raith, M.M., Yakovleva, S.Z. and Kotov, A.B. (2001) The western charnockite zone of the Eastern Ghats belt, India: An independent crustal province of late Archean $(2.8 \mathrm{Ga})$ and Paleoproterozoic (1.7-1.6 Ga) terrains. Gond Research, 4, 666-667.

[12] Mezger, K. and Cosca, M.A. (1999) The thermal history of the Eastern Ghats belt (India) as revealed by $\mathrm{U}-\mathrm{Pb}$ and ${ }^{40} \mathrm{Ar} /{ }^{39} \mathrm{Ar}$ dating of metamorphic and magmatic minerals: Implications for the SWEAT correlation. Precambrian Research, 94, 251-271.

[13] Simmat, R. and Raith, M.M. (2008) U-Th-Pb monazite geochronometry of the Eastern Ghats Belt, India: Timing and spatial disposition of poly-metamorphism. Precambrian Research, 162, 16-39.

[14] Subba Rao, M.V. and Divakara Rao, V. (1988) Chemical constraints on the origin of the charnockites in the Eastern Ghat Mobile belt, India. Chemical Geology, 69, 37-48.

[15] Bhui, U.K., Sengupta, P. and Sengupta, P. (2007) Phase relations in mafic dykes and their host rocks from Kondapalle, Andhra Pradesh, India: Implications for the timedepth trajectory of the Paleoproterozoic (late Archean?) granulites from southern Eastern Ghats belt. Precambrian Research, 156, 153-174.

[16] Wolf, M.B. and Wyllie, P.J. (1994) Dehydration melting of amphibolite at 10 Kbar: Effects of temperature and time. Contributions to Mineralogy and Petrology, 115, 369-383.

[17] Patino Douce, A.E. and Beard, J.S. (1995) Dehydration melting of biotite gneiss and quartz amphibolite from 3 to 15 Kbar. Journal of Petrology, 36, 707-738.

[18] V'ielzeuf, D. and Schmidt, M.W. (2001) Melting relations in hydrous systems revisited: Application to metapelites, metagreywackes and metabasalts. Contributions to Mineralogy and Petrology, 141, 251-267.

[19] Bhattacharya, S. (2003) Dehydration melting in mafic rocks in the Eastern Ghats Belt, India: Implications for variable composition of charnockitic melt and heterogeneity of source rocks. Geological Society of India, 52, 131-144.

[20] Kar, R., Bhattacharya, S. and Sheraton, J.W. (2003) Hornblende dehydration melting in mafic rocks and the link between massif-type charnockite and associated granulites, Eastern Ghats Granulite Belt, India. Contributions to Mineralogy and Petrology, 145, 707-729.

[21] Foley, S., Tiepolo, M. and Vannucci, R. (2002) Growth of early continental crust in subduction zones controlled by melting of amphibolite. Nature, 417, 837-840.

[22] Bhattacharya, S. (2010) Review: The charnockite problem: A twenty-first century perspective. Natural Science, 2, 402-408.

[23] Halden, N.M., Bowes, D.R. and Dash, B. (1982) Struc- 
tural evolution of migmatites in a granulite facies terrane: Precambrian crystalline complex of Angul, Orissa, India. Transactions of the Royal Society, 73, 109-118.

[24] Bhattacharya, S. (1997) Evolution of Eastern Ghats granulite belt of India in a compressional tectonic regime and juxtaposition against Iron Ore craton of singhbhum by oblique collision-transpression. Proceedings of Indian Academy of Sciences, 106, 65-75.

[25] Sen, S.K., Bhattacharya, S. and Acharyya, A. (1995) A multi-stage pressure-temperature record in the Chilka Lake granulites: The epitome of the metamorphic evolution of Eastern Ghats. Journal of Metamorphic Geology, 13, 287-298.

[26] Dasgupta, S. and Sengupta, P. (2003) Indo-Antarctic correlation: A perspective from the Eastern Ghats Granulite belt, India. Geological Society, 206, 131-144.

[27] Bhattacharya, S., Das, P., Chaudhary, A.K. and Saw, A.K. (2010) Mafic granulite xenoliths in the Eastern Ghats Granulite belt: Implications for lower crustal processes in the southeastern Indian Peninsula. Indian Journal of $\mathrm{Ge}$ ology, 80, 55-69.

[28] McCulloch, M.T. and Chappel, B.W. (1982) Nd isotopic characteristics of S- and I-type granites. Earth and Planetary Science Letters, 58, 51-64.

[29] Bhattacharya, S., Kar, R., Teixeira, W. and Basei, M. (2003) High-temperature crustal anatexis in a clockwise P-T path: Isotopic evidence from a granulite-granitoid suite in the Eastern Ghats belt, India. Journal of the Geological Society, 160, 39-46. 